\title{
Keterkaitan Efisiensi Kredit Usaha Rakyat (KUR) dengan Topografi Wilayah di Kabupaten Pati, Provinsi Jawa Tengah
}

\author{
Linkage between the Efficiency of People's Business Credit (KUR) and \\ Regional Topography in Pati District, Central Java Province
}

\author{
Farida Farida $^{1 *}$, Nur Wahyuni ${ }^{1}$ \& Ida Zulfida ${ }^{2}$ \\ ${ }^{1}$ Fakultas Ekonomi dan Bisnis, Universitas Persada Indonesia (YAI), Jalan Diponegoro Nomor 74, Jakarta \\ Pusat 10320; ${ }^{2}$ Program Studi Agroteknologi, Kampus UPMI Medan, Jalan Teladan Nomor 15, Medan 20214; \\ *Penulis korespondensi.e-mail: farida@upi-yai.ac.id \\ (Diterima: 20 Oktober 2018; Disetujui: 29 April 2019)
}

\begin{abstract}
Exogenous factors such as topography of the region are often overlooked in determining the pattern of economic activity. In fact, the geographical surface contributes to the spatial distribution of varied economic activities. The purpose of this study was to see the linkage between the efficiency of the disbursement of People's Business Credit (KUR) program and the topography of the region in Pati Regency-Central Java. The research method is descriptive qualitative by overlaying the efficiency level of 35 KUR channeling banks with polygon maps of each subdistrict in Pati regency. Data on the efficiency level of unit banks are secondary data of each bank unit which has been calculated with Data Envelopment Analysis (DEA) application. Is it dicovered that unit banks are very inefficient at topographies bordered with arid limestone mountains or along rivers that often overflows. As a result, economic activity is not optimal and the disbursement of KUR is not efficient at the area. On the contrary, at topographies in the lowlands, the trade, agriculture, and fisheries sectors are advanced, population is large, economic activities are fast, thus encourage efficient credit disbursement.
\end{abstract}

Keywords: efficiency, microfinance, regional economic activity, topography, KUR

\section{ABSTRAK}

Faktor eksogen seperti topografi wilayah sering terabaikan dalam menentukan corak kegiatan ekonomi. Pada kenyataannya, permukaan geografis menyumbang distribusi spasial kegiatan ekonomi yang bervariasi. Tujuan dari penelitian ini adalah untuk melihat keterkaitan antara efisiensi penyaluran program Kredit Usaha Rakyat (KUR) dengan topografi wilayah di Kabupaten Pati, Provinsi Jawa Tengah. Metode penelitian ini adalah deskriptif kualitatif dengan menumpangtindihkan tingkat efisiensi dari 35 bank unit penyalur KUR dengan peta polygon masing-masing kecamatan di Kabupaten Pati. Data tingkat efisiensi bank-bank unit merupakan data sekunder dari masing-masing bank unit yang sudah dihitung dengan aplikasi Data Envelopment Analysis (DEA). Bank-bank unit yang sangat tidak efisien biasanya memiliki topografi wilayah berbatasan dengan pegunungan kapur yang gersang atau berada di sepanjang aliran sungai yang sering meluap, yang mengakibatkan aktivitas ekonominya tidak optimal dan penyaluran KUR tidak efisien. Sebaliknya, bank-bank unit pada topografi wilayah di dataran rendah, sektor perdagangan, pertanian maupun perikanan maju, jumlah penduduk banyak, aktivitas ekonominya pesat, mendorong penyaluran kredit yang efisien.

Kata kunci: aktivitas ekonomi wilayah, efisiensi, keuangan mikro, Kredit Usaha Rakyat, topografi wilayah 


\section{PENDAHULUAN}

Faktor eksogen seperti topografi wilayah atau bentang alam masih sering terabaikan dalam menentukan corak kegiatan ekonomi wilayah. Padahal, kondisi fisik geografis suatu wilayah sangat mempengaruhi pola kegiatan ekonomi penduduk setempat. Studi Kost et al. (2012) memodelkan variabel topografi yang digunakan sebagai basis penentuan premi risiko spasial dalam asuransi bagi petani. Allen dan Arkolakis (2014) mengembangkan keseimbangan umum untuk menentukan distribusi spasial kegiatan ekonomi dengan mengaitkan permukaan geografi. Lokasi geografi menyumbang sedikitnya $20 \%$ variasi spasial dalam pendapatan di Amerika Serikat.

Topografi wilayah yang mendukung perekonomian akan menjadi pusat pertumbuhan yang semakin menarik, sebaliknya topografi wilayah yang keras akan semakin ditinggalkan. Selama ini teori polarisasi yang menggunakan konsep pusat-pinggiran hendaknya segera diatasi untuk mencegah terjadinya urbanisasi. Pertumbuhan ekonomi perkotaan yang pesat terkadang tidak berimplikasi pada daerahdaerah pinggiran (periphery). Wilayah perdesaan yang memiliki jarak ke kota lebih dekat tentunya memiliki aktivitas ekonomi yang lebih tinggi dibandingkan dengan wilayah perdesaan yang jaraknya jauh dari lokasi perkotaan. Jarak wilayah perdesaan terhadap lokasi pasar ataupun bank akan mempengaruhi akses terhadap kredit. Penelitian Duy et al. (2012) dan Awunyo-Vitor \& Abankwah (2012) membuktikan bahwa jarak atau lokasi sangat signifikan dan berkorelasi negatif terhadap akses kredit formal. Perkotaan dan daerahdaerah inti mendominasi dalam pertumbuhan ekonomi karena efisien secara ekonomi. Kurangnya modal, keahlian, daya beli, dan kemiskinan merupakan faktor semakin terpinggirnya wilayah dengan topografi yang keras.

Mayer et al. (2016) melihat keterkaitan rural-urban dan keberlangsungan pembangunan wilayah yang semakin konvergen karena peranan para pengusaha dari perdesaan yang mampu mengakses pengetahuan dan pasar perkotaan, untuk membawanya ke daerah pinggiran atau perdesaan.

Penyaluran kredit mikro dianggap mahal dan banyak hambatan (Demirgüç-Kunt \& Klapper, 2012) dengan risiko gagal bayar yang tinggi, sehingga kreditur mengenakan tingkat bunga yang tinggi (David \& Rose, 2017) dan agunan. Kenyataannya, suku bunga yang lebih tinggi yang dibebankan ke peminjam berisiko tinggi tidak cukup untuk mengimbangi probabilitas yang lebih tinggi dari default pinjaman (Emekter et al., 2015). Agunan terbukti bertindak sebagai insentif di pasar kredit, sebagai penentu harga pinjaman atau tingkat suku bunga rendah. Agunan juga efektif sebagai alat penyotiran calon peminjam (Gama \& Duarte, 2015), dan berpengaruh positif terhadap akses kredit (Chandio et al., 2017). Sayangnya, banyak calon peminjam yang tidak memiliki agunan.

Selama ini akses permodalan formal murah yang mampu menjangkau masyarakat luas adalah program penyaluran Kredit Usaha Rakyat (KUR). Peranan KUR terbukti mampu meningkatkan pendapatan dan keuntungan, kesempatan kerja dan pemilikan aset usaha mikro (Anggraini \& Nasution, 2013; Sujarweni \& Utami, 2015; Farida et al., 2016) dan secara tidak langsung mampu menurunkan jumlah orang miskin melalui penciptaan lapangan pekerjaan baru. Pembiayaan mikro memiliki pengaruh negatif pada kemiskinan, yang berarti semakin besar pembiayaan mikro disalurkan akan mengurangi tingkat kemiskinan (Zhang, 2017). Sebaliknya, peran keuangan mikro justru mendorong meningkatnya hutang di antara masyarakat miskin dan memperburuk kerentanan ekonomi, sosial dan lingkungan (Banerjee \& Jackson, 2017). Namun, riset yang dilakukan oleh Khan dan Rahaman (2007) di Bangladesh sebagai pioner negara yang mengembangkan model pembiayaan mikro, menganalisis bahwa pembiayaan mikro yang diberikan oleh Grameen Bank, BRAC, ASA dan PROSHIKA memberikan dampak positif terhadap standar hidup orang miskin dan gaya hidupnya. 
Berdasarkan data KUR Kementerian Koordinator Bidang Perekonomian RI (kur.ekon.go.id), realisasi penyaluran KUR tahun 2017 sebesar Rp 95.56 triliun dari target Rp 106 triliun atau hanya 89.6\% saja. Provinsi Jawa Tengah adalah penyalur KUR terbesar mencapai $\mathrm{Rp} 16.90$ triliun diikuti oleh Jawa Timur (Rp 16.3 triliun) dan Jawa Barat (Rp 12.44 triliun). Sektor perdagangan adalah penerima KUR terbesar yaitu $57.71 \%$, sektor pertanian dan kehutanan (23.94\%), sektor jasa $(11.01 \%)$, sektor pengolahan $(5.64 \%)$, dan sektor perikanan (1.65\%). Kabupaten Pati adalah penerima KUR terbesar di Jawa Tengah. Keberhasilan program KUR ke usaha mikro selama ini tidak terlepas dari peran Bank Rakyat Indonesia (BRI), yang memiliki jaringan luas sampai pelosok tanah air. Di Kabupaten Pati, BRI satu-satunya bank penyalur KUR terbesar yang ada, dengan kantor unit BRI di setiap kecamatan. Tentunya target pencapaian penyaluran KUR di masing-masing kecamatan berbeda-beda dengan topografi wilayah yang beragam juga. Topografi wilayah kecamatan yang berbeda, tentunya memiliki keterkaitan dengan kemampuan bank penyalur KUR untuk efisien dan berlanjut. Sektor pertanian dan sektor perikanan di Kabupaten Pati adalah sektor penerima KUR terbesar, tentunya terkait dengan kegiatan utama masyarakat yang sesuai dengan topografi daerah tersebut.

Program KUR diharapkan bisa berkelanjutan. Berkelanjutan berarti bahwa secara finansial, pinjaman KUR tersebut mampu membiayai sendiri semua ongkos pengeluarannya yang berasal dari pendapatan yang diperoleh dari biaya administrasi (bunga) yang dibayar oleh usaha mikro dan meningkatkan usaha produktifnya. Penyedia pinjaman yang mampu beroperasi secara efisien akan berlanjut (Balagobei, 2016), kalau tidak akan tersingkir (Burger et al., 2008) maka terpaksa menurunkan marjin keuntungan. Bank dituntut untuk mampu mengubah dana pihak ketiga sebagai input untuk disalurkan sebagai output (Parasuraman, 2010) dalam bentuk pinjaman seperti KUR.
Kenyataannya, masing-masing bank unit penyalur KUR di Kabupaten Pati tidak semua efisien. Bank-bank unit yang tidak efisien karena penyaluran KUR tidak/kurang optimal. Beberapa bank unit mampu menjangkau luas ke masyarakat, tapi beberapa tidak mampu menjangkau secara luas. Kendala-kendala tersebut dihadapi di lapangan, dimana faktor eksogen seperti topografi wilayah yang dihadapi oleh masing-masing bank unit di setiap kecamatan berbeda-beda. Berdasarkan uraian tersebut, maka penelitian ini bertujuan untuk melihat keterkaitan antara efisiensi penyaluran kredit usaha rakyat dengan topografi wilayah di Kabupaten Pati.

\section{METODE PENELITIAN}

Penelitian dilakukan di wilayah Kabupaten Pati terhadap semua bank unit yang menyalurkan kredit usaha rakyat (KUR) di setiap kecamatan dengan total 35 unit. Data hasil efisiensi merupakan data sekunder yang diperoleh dari jurnal hasil penelitian Farida et al., (2018). Data topografi wilayah merupakan data sekunder yang diperoleh dari BPS Kabupaten Pati. Metode dalam penelitian ini adalah deskriptif kualitatif.

Pengukuran tingkat efisiensi penyalur/ penyedia KUR adalah menggunakan efisiensi teknik (TE) dengan Data Envelopment Analysis (DEA) dengan hasil tingkat masing-masing efisiensi di setiap bank unit yang diperoleh dalam penelitian (Farida et al., 2018). Dikatakan efisien jika hasil teknik efisiensi (TE) sama dengan satu, dan dikatakan tidak efisien jika TE kurang dari satu. Nilai efisiensi DEA ini didefinisikan tidak oleh standar mutlak (Dilts et al., 2015; Thanassoulis \& Silva, 2018) tetapi relatif antara bank-bank unitnya. Fitur inilah yang membedakan DEA dari pendekatan parametrik seperti stochastic frontier approach (SFA), yang membutuhkan bentuk fungsi model tertentu. DEA dipakai dalam penelitian karena masing-masing bank unit memiliki karakteristik yang sama. 
Penghitungan tingkat efisiensi dengan DEA ini berkaitan antara keluaran (output) dengan masukan (input). Output dalam penelitian ini terdiri dari jumlah KUR yang disalurkan, pendapatan bersih bunga, pendapatan provisi dan pendapatan jasa. Sedangkan input yang digunakan dalam model ini adalah simpanan pihak ketiga, beban bunga, beban hadiah, beban penyisihan kerugian, beban tenaga kerja, biaya umum dan biaya operasional lainnya.

Peta poligon Kabupaten Pati dihadirkan dengan memberikan warna sesuai dengan tingkat efisiensi microfinance-nya. Daerah yang bank unitnya efisien diberi warna pink, daerah yang bank unitnya kurang efisien diberi warna hijau, dan daerah yang bank unitnya sangat tidak efisien diberi warna kuning.

\section{HASIL DAN PEMBAHASAN}

\section{Karakteristik KUR dan Bank Penyalur}

Kredit Usaha Rakyat merupakan salah satu program yang dikeluarkan pemerintah berupa pemberian kredit investasi atau pembiayaan modal kerja untuk mendukung UMKM baik perorangan, badan usaha ataupun kelompok produktif yang layak, tetapi belum bankable. Dalam penelitian ini, pembatasan masalah hanya untuk KUR mikro yang diselenggarakan oleh Bank Rakyat Indonesia (BRI) karena lebih 99\% KUR mikro di Kabupaten Pati dilayani oleh BRI.

KUR Mikro Bank BRI merupakan kredit modal kerja dan atau investasi dengan plafon sampai dengan Rp 25 juta per debitur. Debitur adalah individu atau perorangan yang memiliki usaha yang selama ini belum terlayani oleh kredit perbankan untuk usaha, namun layak untuk mendapatkan kredit. Usaha tersebut harus produktif dan sudah aktif minimal enam bulan. Debitur cukup melampirkan KTP, kartu keluarga dan surat keterangan dari kelurahan atau surat izin usaha.
Untuk kredit modal kerja (KMK) memiliki jangka waktu maksimal tiga tahun, sedangkan kredit investasi (KI) memiliki jangka waktu maksimal lima tahun. Mulai Januari 2018, suku bunga efektif per tahun yang diterapkan cukup rendah hanya $7 \%$ atau flat setara $0.58 \%$ setiap bulan. Kredit-kredit tersebut tidak dikenakan biaya provisi dan administrasi.

Berdasarkan data Kementerian

Koordinator Bidang Perekonomian RI (kur.ekon.go.id) realisasi penyaluran KUR mengalami peningkatan yang signifikan dari tahun ke tahun, meskipun masih lebih rendah dari target yang ditetapkan. Pada tahun 2018, pemerintah menargetkan Rp 140 triliun, namun realisasi penyaluran kredit sebesar Rp 120.35 triliun dengan jumlah nasabah sebanyak 4.44 juta.

BRI sebagai satu-satunya bank yang memiliki unit terbanyak dan mampu menjangkau masyarakat luas, telah menjadikan sebagai satu-satunya bank yang mampu menyalurkan kredit kepada para pengusaha mikro. Bank-bank lain yang diberikan kewenangan untuk menyalurkan kredit kepada usaha mikro memilih untuk melayani usaha kecil menengah karena lebih efisien dan menguntungkan. Kenyataannya, tingkat gagal bayar (non-performance loan) para nasabah mikro sebenarnya lebih kecil dibandingkan dengan para nasabah menengah.

\section{Inefisiensi Penyaluran KUR Berdasarkan Tipologi Wilayah Pati}

Dari total 35 bank unit penyalur KUR di Kabupaten Pati, Berdasarkan penelitian (Farida et al., 2018) mengungkapkan bahwa bank-bank unit dikatakan efisien apabila secara teknik baik dengan pendekatan constant return scale (CRS) maupun variabel return scale (VRS) memiliki skala efisiensi (SE) dengan score satu. Dikatakan tidak efisien jika tidak sama dengan satu. 
Model DEA CRS dan DEA VRS digunakan untuk menentukan kecenderungan tren pada bank-bank unit penyalur KUR di lokasi penelitian yang tergolong pada increasing return to scale (IRS) atau peningkatan output lebih besar daripada peningkatan input ada 11 unit $(31.43 \%)$.
Sementara bank unit yang tergolong pada decreasing return to scale (DRS) atau peningkatan input lebih besar daripada peningkatan output ada 6 unit (17.14\%) dan sisanya 18 unit $(51.43 \%)$ berada pada tingkat efisien.

Tabel 1 Bank-bank unit penyalur KUR yang tidak efisien

\begin{tabular}{llll}
\hline No & Nama Bank Unit & Skala Efisiensi (SE) & Return to scale (RTS) \\
\hline 1 & Bulu Manis & 0.993 & IRS \\
2 & Gabus & 0.988 & DRS \\
3 & Gembong & 0.987 & DRS \\
4 & Jaken & 0.980 & IRS \\
5 & Jakenan & 0.861 & IRS \\
6 & Margorejo & 0.965 & DRS \\
7 & Mulyoharjo & 0.961 & IRS \\
8 & Tambakromo & 0.965 & DRS \\
9 & Wedaruaksa & 0.961 & IRS \\
10 & Winong & 0.999 & IRS \\
11 & Juwono 1 & 0.997 & DRS \\
12 & Pati Kota 1 & 0.992 & IRS \\
13 & Tayu & 0.996 & IRS \\
14 & Ngablak & 0.986 & DRS \\
15 & Pagerharjo & 0.993 & IRS \\
16 & Pekalongan & 0.951 & IRS \\
17 & Pucakwangi & 0.926 & IRS \\
\hline Rata-rata & 0.987 & \\
\hline Minimum & 0.861 & \\
\hline Maksimum & 0.999 & \\
\hline
\end{tabular}

Sumber: Farida et al. (2018)

Pada Tabel 1, skala efisiensi dibawah satu berarti inefisien. Rata-rata inefisiensi dalam skala efisiensi adalah 0.987, dan inefisiensi tertinggi dicapai oleh bank unit
Jakenan sebesar 0.861, sedangkan inefisiensi terendah dicapai oleh bank unit Winong sebesar 0.999 .

Tabel 2 Frekuensi skala efisiensi bank-bank unit penyalur KUR

\begin{tabular}{llll}
\hline Kategori & Skala efisiensi & Jumlah & Prosentase \\
\hline Efisien & 1 & 18 & $51.43 \%$ \\
Inefisien rendah & $0.931-0.999$ & 15 & $42.86 \%$ \\
Inefisien tinggi & $0.861-0.930$ & 2 & $5.71 \%$ \\
\hline
\end{tabular}

Inefisien dikategorikan menjadi dua yaitu inefsien tinggi dan inefisien rendah seperti di Tabel 2. Efisiensi dalam penelitian ini adalah relatif, dan hasilnya menunjukkan sebagian besar bank-bank unit penyalur kredit usaha rakyat (KUR) ini efisien (warna pink) sebanyak 18 unit atau $51.43 \%$.
Inefisien rendah (warna hijau) sebanyak 15 unit atau $42.86 \%$, dan sisanya $5.71 \%$ merupakan inefisien tinggi (warna kuning) sebanyak dua unit yaitu bank unit Jakenan dan bank unit Pucakwangi. 
Tabe1 3 Inefisiensi tinggi penyaluran KUR berdasarkan pola tipologi wilayah bank-bank unit penyalur KUR yang tidak efisien

\begin{tabular}{|c|c|c|c|}
\hline No. & Tipologi Wilayah & Skor & Karakteristik \\
\hline & Kec. Pucakwangi: & 0.926 & \\
\hline 1. & $\begin{array}{l}\text { Sumber daya fisik } \\
\text { wilayah }\end{array}$ & & $\begin{array}{l}\text { Pegunungan kapur. Sebagai kecamatan paling ujung } \\
\text { menyebabkan wilayah ini kurang aktivitas ekonominya } \\
\text { dibandingkan dengan wilayah lain, sehingga mendorong } \\
\text { penyaluran KUR yang kurang optimal dan sangat tidak efisien } \\
\text { apalagi penyaluran KUR diperebutkan oleh dua bank unit yaitu } \\
\text { Pucakwangi dan Karangwotan. Karangwotan mampu mencapai } \\
\text { efisien karena letaknya berbatasan dengan kecamatan lain } \\
\text { Winong yang arus uang dan kegiatan ekonomi lebih bergeliat, } \\
\text { sedangkan Pucakwangi berbatasan dengan pegunungan, dimana } \\
\text { aktivitas ekonominya kurang. }\end{array}$ \\
\hline 2. & $\begin{array}{l}\text { Sumber daya } \\
\text { manusia }\end{array}$ & & $\begin{array}{l}\text { Jumlah penduduk di Kec. Pucakwangi hanya } 40,847 \text { termasuk } \\
\text { lima terkecil dengan } 10,865 \text { penduduknya miskin yang berarti } \\
\text { skala ekonomi dalam penyaluran KUR pun kecil. }\end{array}$ \\
\hline \multirow[t]{2}{*}{ No. } & Tipologi Wilayah & Skor & Karakteristik \\
\hline & Kec. Jakenan & 0.861 & \\
\hline 1. & $\begin{array}{l}\text { Sumber daya fisik } \\
\text { wilayah }\end{array}$ & & $\begin{array}{l}\text { Daerah barat Jakenan merupakan DAS Sungai Juwana yang } \\
\text { setiap musim penghujan menjadi langganan banjir akibat } \\
\text { meluapnya Sungai Juwana. Pada awal tahun 2008, banjir } \\
\text { menenggelamkan daerah barat Kecamatan Jakenan hingga } \\
\text { kedalaman } 3.5 \text { meter yang berlangsung selama lebih dari satu } \\
\text { bulan. Faktor ini yang mendorong penyaluran KUR di } \\
\text { kecamatan ini tidak optimal dan sangat tidak efisien. Seringnya } \\
\text { bencana karena topografi wilayah Jakenan yang lebih rendah } \\
\text { dari sungai, mengakibatkan roda ekonomi lambat, sehingga } \\
\text { penyaluran KUR maupun mobilisasi dana masyarakat kurang } \\
\text { efisien. }\end{array}$ \\
\hline 2. & $\begin{array}{l}\text { Sumber daya } \\
\text { manusia }\end{array}$ & & $\begin{array}{l}\text { Jumlah penduduk di Kec. Jakenan hanya } 40,588 \text { termasuk dua } \\
\text { terkecil dengan } 11,625 \text { penduduknya miskin yang berarti skala } \\
\text { ekonomi dalam penyaluran KUR pun kecil. }\end{array}$ \\
\hline 3. & Aktivitas ekonomi & & $\begin{array}{l}\text { Mata pencaharian penduduk Kecamatan Jakenan sebagian } \\
\text { besar adalah bertani dengan memanfaatkan lahan pertanian } \\
\text { berupa sawah tadah hujan. Sebagian lagi menggantungkan } \\
\text { hidup sebagai buruh pada berbagai industri yang ada di kota } \\
\text { Juwana dan Pati Kota. Karena minimnya lapangan pekerjaan } \\
\text { yang tersedia maka tidak sedikit warga yang pergi merantau ke } \\
\text { lain daerah bahkan ke luar negeri, seperti umumnya warga } \\
\text { Kabupaten Pati lainnya. Kurangnya aktivitas ekonomi } \\
\text { menyebabkan kurang optimalnya penyaluran KUR. }\end{array}$ \\
\hline
\end{tabular}

Kedua bank unit yang inefisiennya tinggi yaitu Jakenan dan Pucakwangi tersebut berada di wilayah Pati bagian selatan. Wilayah lain yang tidak efisien atau inefisien rendah ada 15 dari bank unit yaitu Bulumanis, Gabus, Gembong, Jaken, Margorejo, Mulyoharjo, Tambakromo, Wedarijaksa, Winong, Juwono 1, Pati Kota 1, Tayu, Ngablak, Pagerharjo dan Pekalongan

Kecamatan Widarijaksa. Wilayah Kecamatan Widarijaksa merupakan wilayah bank unit yang tidak efisien karena kecamatan ini merupakan wilayah tersempit kedua di
Kabupaten Pati. Sebagai wilayah tersempit kedua mempengaruhi penyaluran KUR yang tidak optimal sehingga terjadi inefisien. Apalagi di kecamatan ini terdapat dua bank unit (Wedarijaksa dan Pagerharjo), keduanya penyaluran KUR tidak efisien.

Letak Kecamatan Wedarijaksa ke arah utara Kota Pati sekitar $9 \mathrm{~km}$. Dari permukaan laut sekitar 1-28 meter, dengan tipe tanah Latosol, Regosol, dan Red Yellow Mediteran. Luas wilayah sekitar 4 ribu hektar terbagi atas lahan sawah hampir 2 ribu hektar, dan sisanya lahan bukan sawah. Jumlah penduduk 57.6 ribu 
jiwa, perempuan sekitar 29 ribu dan sisanya sekitar 28.6 ribu laki-laki. Mayoritas penduduk sebagai petani padi, tebu, palawija dan buahbuahan. Ada enam pasar tradisional, termasuk satu di pusat kota kecamatan.

Kecamatan Jaken. Kecamatan Jaken berbatasan dengan wilayah kabupaten Rembang, berjarak $30 \mathrm{~km}$ ke arah timur kota Pati. Luas wilayahnya $58.5 \mathrm{~km}$ persegi dengan jumlah penduduk 45.2 ribu jiwa yang tersebar di 21 desa. Di bagian selatan Kecamatan jaken ini dibatasi oleh pegunungan kapur utara. Kurangnya aktivitas ekonomi dibandingkan dengan kecamatan lain mendorong penyaluran KUR tidak optimal di wilayah ini.

Kecamata Winong. Bank unit Pekalongan dan Winong berada di wilayah Kecamatan Winong. Keberadaan dua bank unit dalam suatu wilayah kecamatan menyebabkan masing-masing bank unit kurang optimal dan tidak efisien dalam menyalurkan KUR meskipun bank unit Winong inefisiensinya 0.999. Meskipun kecamatan Winong merupakan kecamatan dengan ibukota kecamatan terbesar setelah Pati, Juwono dan Tayu, tapi nampaknya penyaluran KUR belum optimal.

Kecamatan Margoyoso. Di kecamatan ini terdapat dua bank unit yaitu Bulumanis yang tidak efisien dan Ngemplak yang mampu efisien. Nelayan dan petani tambak merupakan mayoritas mata pencaharian di kecamatan ini. Terdapat industri tapioka di Desa Ngemplak Kidul. Dengan adanya industri di desa Ngemplak ini mendorong penyaluran KUR di bank unit Ngemplak bisa optimal. Adanya Makam Syekh Ronggo Kusumo (di Desa Ngemplak Kidul) dan Makam Syekh Akhmad Mutamakkin (di Desa Kajen) bisa menjadi tujuan wisata religi, selain juga terdapat wisata alam Tambak Buntu. Hal ini yang mendorong kegiatan aktivitas ekonomi di wilayah ini meningkat.

Kecamatan Margorejo. Secara geografis kecamatan ini berada di wilayah barat Kabupaten Pati. Terdiri dari 18 desa, 28 dukuh, 62 rukun warga dan 318 rukun tetangga. Jumlah penduduk 56,731 orang. Topografi permukaan daratan kecamatan ini relatif datar dengan sedikit perbukitan. Luas tanah sekitar 6,181 hektar, terbagi tanah sawah seluas 2,755 hektar dan bukan sawah seluas 3,426 hektar. Di wilayah bagian selatan Kecamatan Margorejo merupakan dataran rendah dilalui Sungai Silugonggo yang cukup besar, dan setiap tahun menggenangi Desa Langenharjo, Desa Penambuhan dan Desa Jambean Kidul. Kerugian yang ditimbulkan oleh banjir ini sangat besar. Dengan kondisi seperti ini mempengaruhi penyaluran KUR karena bank menghindari gagal kredit.

Kecamatan Juwono. Selain Pati, Kota Juwono adalah kota terbesar di pesisir utara Pulau Jawa menuju ke Kabupaten Rembang. Terkenal dengan industri kuningan dan budidaya bandeng. Sayangnya, kota ini sering terkena banjir karena dilalui Sungai Juwono/Sungai Silugonggo. Luas wilayah sekitar 5.5 ribu hektar. Di Kecamatan ini terdapat dua bank unit penyalur KUR, yaitu Juwono 1 dan Juwono 2. Dari kedua bank unit tersebut satunya efisien dan satunya inefisien. Seperti halnya di kecamatan-kecamatan lainnya, untuk keberadaan dua bank unit dalam satu kecamatan menyebabkan salah satunya tidak efisien.

Berpenduduk total sekitar 87.4 ribu, yaitu laki-laki sekitar 43.5 ribu dan perempuan 43.9 ribu. Sebagai daerah pesisir, mata pencaharian utama sebagai petani tambak, nelayan dan buruh. Kerajinan dan tambak cukup maju di Kecamatan Juwono, selain juga ada industri rokok, maupun pabik minyak kacang. Adanya pelabuhan Juwono menambah ramai lalu lintas perdagangan di wilayah Kecamatan Juwono.

Kecamatan Gembong. Lokasi geografis Kecamatan Gembong berada di lereng perkebunan kopi Gunung Muria, tepatnya di Desa Jolong. Kecamatan ini berbatasan dengan Kabupaten Kudus. Hanya Kecamatan Gembong yang memiliki dua waduk yaitu Waduk Seloromo dan Waduk Gunung Rowo. Dari ibukota Pati berjarak $14 \mathrm{~km}$ ke arah barat laut. Sebagian besar wilayah merupakan hutan dan perkebunan, dengan ketinggian diatas permukaan laut sekitar 20-900 meter. Total 
luas wilayah adalah sekitar 6.73 ribu hektar, dan secara administratif memiliki jumlah desa paling sedikit yaitu 11 desa dengan $85 \mathrm{RW}$ dan 276 RT. Jenis tanah mayoritas berupa Latosol.

Jumlah desa yang sedikit berarti jumlah penduduk juga lebih sedikit sekitar 40,780 jiwa. Hal ini menyebabkan penyaluran KUR belum optimal. Dengan mata pencaharian mayoritas petani dan buruh perkebunan, jangkauan penyaluran KUR selama ini belum optimal kepada mereka. Petani dan buruh masih dianggap pihak yang tidak bankable, baik secara administratif maupun bidang usaha.

Kecamatan Gabus. Di bagian utara Kecamatan Gabus dibatasi Sungai Juwono yang airnya selalu meluap setiap musim hujan. Sebelumnya, Kecamatan ini bagian dari Kawedana Kayen. Luas sekitar 5.55 ribu hektar yang berada di sebelah utara Kota Pati. Ketinggian dari permukaan laut sekitar 5-30 meter, sebagai daerah dataran dengan jenis tanah Alluvial.

Sebenarnya di wilayah ini pertanian, perikanan dan perdagangan cukup maju, sehingga terdapat 3 unit bank penyalur KUR yaitu bank unit Karaban, Tambahmulya dan Gembong. Sehingga penyaluran KUR di wilayah ini cukup ketat. Namun, dari ketiganya, hanya bank unit Gembong yang kurang efisien karena wilayah sekitar Gembong sering terkena luapan banjir Sungai Juwono.

Kecamatan Tayu. Selain Kecamatan Pati dan Juwana, Tayu juga termasuk kecamatan yang cukup maju. Jaraknya sekitar $27 \mathrm{~km}$ dari Kota Pati dan merupakan jalur menuju Kabupaten Jepara. Ketinggian dari permukaan laut sekitar 1-41 meter, dengan tanah berjenis Aluvial, Red Yellow Mediteran dan Regosol. Total luas wilayah sekitar 4.76 ribu hektar yang terbagi persawahan 2 ribu hektar, dan sisanya lahan non sawah 2.7 ribu hektar. Kecamatan Tayu secara administratif memiliki 21 desa (72 RW dan 368 RT).

Di kecamatan ini terdapat dua bank unit penyalur KUR yaitu (Tayu dan Pakis). Bank unit Pakis mengalami optimal dan efisien dalam penyaluran KUR karena tingkat aktivitas ekonomi di daerah ini tinggi didorong keberadaannya pabrik gula di wilayah ini. Sebaliknya bank unit Tayu kurang efisien. Biasanya dalam satu wilayah dengan dua atau lebih bank unit, salah satunya relatif kurang efisien. Jumlah penduduk Kecamatan Tayu total sekitar 68.54 ribu jiwa, terdiri atas 34.07 ribu laki-laki dan 34.47 ribu penduduk perempuan.

Kecamatan Tambakromo. Kecamatan Tambakromo terletak di bagian selatan Kabupaten Pati. Berbatasan dengan Kabupaten Grobogan oleh pegunungan kapur. Sebelumnya kecamatan ini masuk Kawedanan Kayen. Di kecamatan ini terdapat dua bank unit yaitu Angkatan Lor dan Tambakromo. Bank unit Angkatan Lor mencapai penyaluran KUR yang optimal sebaliknya bank unit Tambakromo kurang efisien. Bank unit Tambakromo letaknya dekat dengan pegunungan kapur yang tandus, sehingga aktivitas ekonomi relatif tidak semaju bank unit Angkatan Lor. Kecamatan ini mempunyai luas wilayah sekitar $72.47 \mathrm{~km}^{2}$ dengan sebagian besar adalah daerah persawahan. sementara jumlah penduduk daerah tersebut sekitar 47,660 jiwa, terdiri dari 22.9 ribu laki-laki dan 24.75 perempuan serta berkepadatan 730.29 jiwa $/ \mathrm{km}^{2}$. Dari luas wilayah tersebut penduduknya tersebar di 18 desa. Pendduk tersebut sebagian besar adalah petani, selain itu juga adalah pedagang dan sebagian besar sebagai perantau atau buruh migran. Perekonomian daerah tersebut tergolong maju, karena ditopang oleh banyaknya buruh migran. Sementara untuk pendidikan daerah ini tidak begitu menonjol di banding kecamatan-kecamatan pati lainya. Sebagai daerah pegunungan, daerah ini mempunyai beberapa tempat wisata yang menjadikan kegiatan ekonomi semakin meningkat.

\section{Efisiensi Penyaluran KUR Berdasarkan Pola Tipologi Wilayah Pati}

Bank-bank unit yang masuk kategori efisiensi dengan skala efisiensi (SE) 1 adalah Pati Kota 2, Batangan, Dukuh Seti, Juwono 2, Kajar, Karaban, Kayen, Ngemplak, Sukolilo, Angkatan Lor, Gunung Wungkal, Karang 
Wotan, Pakis, Plaosan, Tambak Mulyo, Tlogorejo, Tambaharjo, dan Cengkal Sewu.

Beberapa wilayah yang ada di Kabupaten Pati berdasarkan Gambar 1, bank-bank unit nya mencapai penyaluran KUR yang optimal dan efisien. Kegiatan ekonomi yang tinggi dan didukung oleh tipologi wilayah mendorong bank-bank unit mencapai optimal. Namun biasanya di suatu wilayah dimana memiliki lebih dari satu bank unit maka salah satunya tidak efisien. Hanya Kecamatan Sukolilo saja yang memiliki lebih dari satu bank unit namun keduanya mengalami optimal dan efisien.

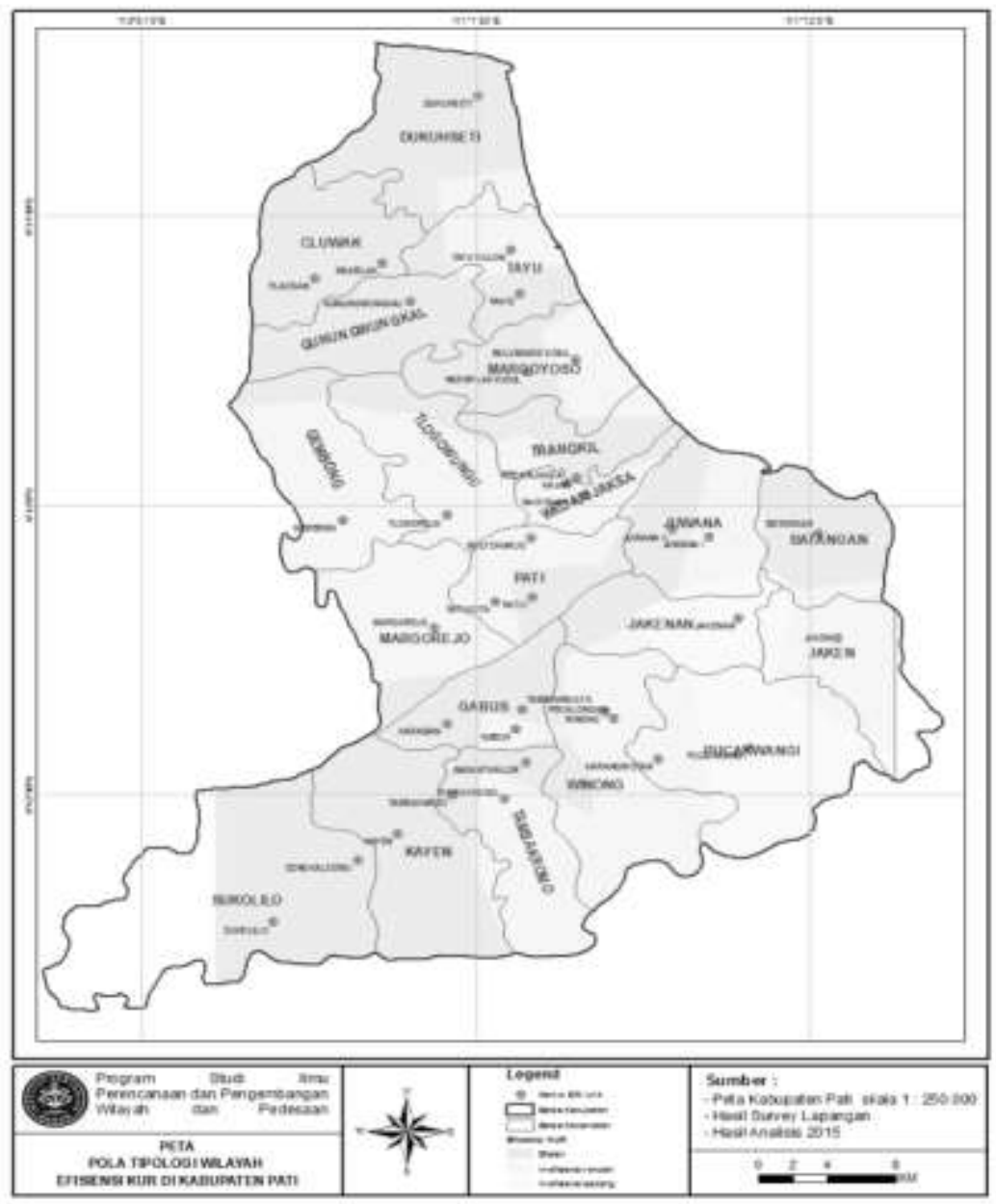

Gambar 1 Peta tipologi wilayah berdasarkan tingkat efisiensi penyaluran KUR di Kab. Pati Sumber: BPS

Tabel 4 Efisiensi penyaluran KUR berdasarkan pola tipologi wilayah

\begin{tabular}{|c|c|c|c|}
\hline No & $\begin{array}{l}\text { Topologi } \\
\text { Wilayah }\end{array}$ & Skor & Karakteristik \\
\hline & (Kec. Sukolilo): & 1/efisien & \\
\hline 1. & $\begin{array}{l}\text { Sumber daya } \\
\text { fisik wilayah }\end{array}$ & & $\begin{array}{l}\text { Dataran rendah dimana secara topologi cocok buat tanah pertanian. } \\
\text { Wilayah Sukolilo merupakan kecamatan paling luas yang berarti } \\
\text { skala ekonominya besar. }\end{array}$ \\
\hline 2. & $\begin{array}{l}\text { Sumber daya } \\
\text { manusia }\end{array}$ & & $\begin{array}{l}\text { Jumlah penduduk di Kec. Sukolilo terbesar ketiga mencapai } \\
80,426 \text { yang berarti skala ekonomi dalam penyaluran KUR pun } \\
\text { paling tinggi. }\end{array}$ \\
\hline 3. & $\begin{array}{l}\text { Aktivitas } \\
\text { ekonomi }\end{array}$ & & $\begin{array}{l}\text { Dengan luasnya areal pertanian, maka pertanian merupakan sektor } \\
\text { utama yang menopang perekonomian wilayah ini. Pertambangan } \\
\text { dan wisata juga merupakan sektor penting dalam menggerakkan } \\
\text { aktivitas ekonomi. }\end{array}$ \\
\hline
\end{tabular}


Tabel 4 Lanjutan

\begin{tabular}{|c|c|c|c|}
\hline No & $\begin{array}{l}\text { Topologi } \\
\text { Wilayah }\end{array}$ & Skor & Karakteristik \\
\hline & (Kec. Dukuhseti) & 1/efisien & \\
\hline 1. & $\begin{array}{l}\text { Sumber daya } \\
\text { fisik wilayah }\end{array}$ & & $\begin{array}{l}\text { Merupakan dataran rendah yang membujur langsung ke Laut Jawa. } \\
\text { Wilayah Dukuhseti merupakan kecamatan terluas no } 5 \text {, sehingga } \\
\text { skala ekonominya cukup luas untuk penyaluran KUR }\end{array}$ \\
\hline 2. & $\begin{array}{l}\text { Sumber } \\
\text { manusia }\end{array}$ & & $\begin{array}{l}\text { Jumlah penduduk mencapai } 56,777 \text { terbesar ke- } 9 \text { dengan tingkat } \\
\text { aktivitas ekonomi yang tinggi membuka peluang penyaluran KUR } \\
\text { bisa maksimal dan menpai efisiensi. }\end{array}$ \\
\hline 3. & $\begin{array}{l}\text { Aktivitas } \\
\text { ekonomi }\end{array}$ & & $\begin{array}{l}\text { Perikanan menjadi andalan sumber perekonomian di wilayah ini } \\
\text { selain pertanian. Industri rumah tangga juga banyak tumbuh di } \\
\text { wilayah ini seperti Batik Bakalan. Industri kecil dan mikro yang } \\
\text { terbanyak adalah industri gerabah/keramik/batu bata dengan } \\
\text { jumlah } 499 \text { unit disusul industri makanan dan minuman. Seiring } \\
\text { dengan pesatnya ekonomi di wilayah kecamatan Dukuhseti ini } \\
\text { diperkirakan yang mendorong permintaan terhadap KUR tinggi } \\
\text { dan pencapaiannya bisa optimal dan efisien. }\end{array}$ \\
\hline
\end{tabular}

Kecamatan Sukolilo. Di kecamatan ini terdapat dua bank unit (Sukolilo dan Cengkal Sewu) yang keduanya mencapai efisien dalam penyaluran KURnya. Letak Kecamatan ini paling selatan di Kabupaten Pati, dan berbatasan langsung dengan Kabupaten Blora di sebelah selatan. Sementara bagian utara Kecamatan Sukolilo berbatasan dengan Kecamatan Kayen. Kecamatan Sukolilo adalah kecamatan paling besar yang berada di Kabupaten Pati dengan total luas wilayah 158.7 $\mathrm{km}^{2}$. Berpenduduk 84.4 ribu jiwa terdiri dari 41.64 ribu laki-laki dan 42.78 ribu perempuan. Jadi tingkat kepadatan penduduk mencapai $531.85 \mathrm{jiwa} / \mathrm{km}^{2}$, menyebar di 16 desa (483 RT dan $80 \mathrm{RW}$ ). Dengan luasnya wilayah dan jumlah penduduk yang tinggi mendorong penyaluran KUR kedua bank unit mampu mencapai optimal dan efisien.

Sebagai kecamatan terluas, lahan sawah mencapai 7.25 ribu hektar dan 8.62 ribu hektar lahan bukan sawah, kecamatan ini menjadikan sektor pertanian sebagai penopang perekonomian wilayah tersebut. Selain itu, adanya pertambangan karst dan keberadaan wisata alam dan budaya di kecamatan ini mendorong perekonomian masyarakat maju. Potensi pertanian yang cukup besar di kecamatan Sukolilo meliputi pertanian tanaman pangan, perkebunan, kehutanan, dan peternakan.

Kecamatan Dukuhseti. Kecamatan ini jauh dari pusat kota Pati sekitar $36 \mathrm{~km}$ ke arah utara. Merupakan daerah dataran rendah dan kota pesisir laut Jawa. Ketinggian dari permukaan laut sekitar 1-40 meter, terbagi 12 desa (46 RW dan 342 RT). Total jumlah penduduk sekitar 57.72 ribu jiwa, laki-laki 29.18 ribu dan perempuan 28.54 ribu. Di Kecamatan ini berbatasan dengan laut Jawa sehingga banyak usaha rumah tangga berkaitan dengan perikanan. Sebelah timur kecamatan inilah menjadi sumber pendapatan masyarakat Dukuhseti. Industri rumah tangga juga banyak tumbuh di wilayah ini seperti Batik Bakalan. Industri kecil dan mikro yang terbanyak adalah industri gerabah/keramik/batu bata dengan jumlah 499 unit disusul industri makanan dan minuman. Seiring dengan pesatnya ekonomi di wilayah kecamatan Dukuhseti ini diperkirakan yang mendorong permintaan terhadap KUR tinggi dan pencapaiannya bisa optimal dan efisien.

Kecamatan Cluwak (bank unit Plaosan dan Ngablak). Di bidang perekonomian, Kecamatan Cluwak memiliki 3 buah pasar tradisional. Pasar tersebut terdapat di Desa Ngablak yang melayani 13 desa (74 RW dan 287 RT) atau total jumlah penduduk sekitar 44 ribu jiwa, dimana laki-laki mencapai 22 ribu jiwa dan perempuan setengahnya. Kecamatan Cluwak memiliki kegiatan ekonomi yang tinggi. Dengan adanya dua unit bank penyalur KUR di kecamatan ini, maka salah satu mampu mencapai penyaluran yang optimal dan efisien 
yaitu bank unit Plaosan dan yang satunya kurang efisien yaitu bank unit Ngablak.

Kecamatan ini berjarak $39 \mathrm{~km}$ dari Kota Pati ke arah utara. Jenis tanahnya Latosol, berada di lereng Gunung Muria dengan ketinggian dari atas permukaan laut sekitar 15282 meter.

Kecamatan Batangan. Terletak di ujung timur Kabupaten Pati yang berjarak lebih kurang 22 meter. Kecamatan ini juga berada di pesisir Laut Jawa, yang sebelumnya bagian dari Kawedanan Juwana. Luas wilayah hanya 5.07 ribu hektar, terbagi menjadi 18 desa (52 RW dan 266 RT), masuk lima terkecil di Kabupaten Pati. Kecamatan kecil lainnya yaitu Kecamatan Pati, Kecamatan Wedarijaksa, Kecamatan Trangkil dan Kecamatan Tayu.

Total jumlah penduduk sebanyak 40.8 ribu jiwa, 20.29 ribu penduduk laki-laki dan 20, 51 ribu perempuan. Sebagian besar penduduk mengandalkan pendapatan sebagai petani, petani tambak dan nelayan. Komoditas andalan yaitu tanaman padi, tambak Udang Windu dan bandeng. Aktivitas ekonomi terkonsentrasi di pasar tradisional di Desa Kuniran yang beroperasi tiga kali seminggu yaitu hari Minggu, Selasa dan Jumat. Sementara di kecamatan tetangga yaitu Kecamatan Jaken yang jaraknya hanya sekitar $3 \mathrm{~km}$ juga terdapat pasar Ngulakan yang operasionalnya berbeda hari dengan pasar Kuniran. Sebagai wilayah pesisir, Kecamatan Batangan juga memiliki Tempat Pelelangan Ikan (TPI) di Desa Pecangaan. Dengan adanya TPI ini maka akan semakin meningkatkan aktivitas kegiatan ekonomi di wilayah tersebut sehingga kebutuhan modal dan penyaluran KUR sangat diharapkan.

Kecamatan Trangkil (bank unit Kajar) Jarak dari Kota Pati ke arah utara sekitar $11 \mathrm{~km}$. Di ketinggian 1-36 meter dari permukaan laut dengan jenis tanah Regosol, Latosol dan sebagian lagi berjenis Red Yellow Mediteran. Total luas wilayah 4.28 ribu hektar, terbagi lahan persawahan seluas 1.04 ribu hektar dan sisanya lahan bukan sawah seluas 3.25 ribu hektar. Kecamatan ini terkecil ketiga setelah Kecamatan Pati dan Kecamatan Wedarijaksa.
Jumlah penduduk mencapai 60.33 ribu jiwa dengan komposisi 29.8 ribu jiwa laki-laki dan sisanya 30.53 ribu jiwa perempuan.

Mayoritas penduduk adalah petani dengan komoditas unggulan adalah padi, tebu, palawija dan tanaman buah. Aktivitas ekonomi terpusat di dua pasar tradisional yang salah satunya ada di pusat kota kecamatan. Selain sebagai petani, sebagian penduduk bekerja di sebuah pabrik gula yaitu PG. Trangkil, yang memiliki kapasitas giling 4,500 tth. Dengan adanya pabrik ini geliat ekonomi di wilayah ini hidup. Banyaknya pondok pesantren di wilayah ini meningkatkan santri pendatang dan aktivitas ekonomi meningkat, sehingga penyaluran KUR diperkirakan mampu optimal.

Kecamatan Tlogowungu (bank unit Tlogorejo). Jaraknya sekitar $6 \mathrm{~km}$ ke arah utara dari kota Pati. Kecamatan ini berada di lereng timur Gunung Muria dengan jenis tanah latosol dan Red Yellow Mediteran. Mata pencaharian utama adalah pertanian padi, buah-buahan, sayuran dan tanaman hias, selain juga tanaman keras pohon jati. Selain sebagai daerah yang subur, kecamatan ini termasuk terluas kelima setelah Kecamatan Sukolilo, Kecamatan Pucakwangi, Kecamatan Winong dan Kecamatan Kayen yaitu 9.45 ribu hektar. Kecamatan ini memiliki jumlah desa paling sedikit keempat setelah Kecamatan Gembong, Kecamatan Dukuhseti dan Kecamatan Cluwak. Kecamatan Tlogowungu secara administratif, tersebar di $15 \quad(70 \quad$ RW dan 318 RT). Berpenduduk sekitar 49.6 ribu terdiri dari lakilaki 24.6 ribu dan perempuan sekitar 24.39 ribu jiwa.

Selain menitik-beratkan sektor pertanian, kecamatan ini juga mengandalkan tempattempat seperti; Sendang Tirta Marta Sani, Bumi Perkemahan Regaloh, dan Bumi Perkemahan Jolong. Ada juga air terjun Santi Tretes, dan air terjun Jenar.

Dengan kondisi tanah pertanian yang subur dan banyaknya tempat wisata di wilayah ini diperkirakan yang mendorong semakin meningkatnya kegiatan ekonomi dan penyaluran KUR bisa optimal dan mencapai 
efisien apalagi di wilayah ini hanya ada satu bank unit Tlogorejo.

Kecamatan Gunung Wungkal. Bank unit Gunung Wungkal yang berada di kecamatan ini mampu mencapai kinerja penyaluran KUR yang optimal dan efisien. Meski luas wilayah terkecil hanya $61.80 \mathrm{~m}^{2}$, yang terdiri dari persawahan dan perbukitan, namun tanahnya subur. Jumlah penduduk sekitar 34.95 ribu terdiri dari 17.56 ribu lakilaki dan perempuan sekitar 17.39 ribu. Meski demikian satu-satunya bank penyalur KUR di wilayah ini, yaitu bank unit Gunung Wungkal mampu mencapai efisien.

Kecamatan Pati Kota. Desa yang berada di Kecamatan Pati ini banyak sekitar 29 desa. Aktivitas di tengah kota sangat tinggi, sehingga kehadirannya KUR sangat diharapkan oleh rumah tangga usaha mikro. Permintaan KUR pastilah sangat luas sehingga di kecamatan ini terdapat empat bank unit yaitu (Pati Kota 1, Pati Kota 2, Mulyoharjo dan Tambaharjo). Pati Kota 2 dan Tambaharjo merupakan bank unit yang mampu beroperasi secara optimal sedangkan Pati Kota 1 dan Mulyoharjo tidak efisien. Jumlah penduduk di kecamatan ini hampir dua kalinya dibandingkan dengan kecamatan-kecamatan lainnya yaitu sekitar 108,930 jiwa yang tersebar di wilayah seluas $42.49 \mathrm{~km}^{2}$ dengan kepadatan mencapai $2,564 \mathrm{jiwa} / \mathrm{km}^{2}$.

Kecamatan Kayen. Di kecamatan ini hanya terdapat satu bank unit saja yaitu bank unit Kayen dan mampu menyalurkan KUR terbanyak di Kabupaten Pati. Bank unit ini mampu menekan biaya operasionalnya semakin hemat, namun pendapatannya malah meningkat. Sektor pertanian maju dengan panen yang melimpah karena areal pertanian yang subur dan luas. Irigasi yang memadai untuk pertanian maupun perikanan air tawar mendorong aktivitas ekonomi di Kecamatan Kayen berkembang, telah mendorong penyaluran KUR yang optimal dan efisien.

\section{SIMPULAN DAN REKOMENDASI}

Topografi daerah berimplikasi pada corak kegiatan ekonomi masyarakat. Topografi pegunungan, gurun, tanah kapur secara alamiah menghambat kegiatan ekonomi. Pada daerah tersebut jumlah penduduk akan sedikit karena banyak orang yang berurbanisasi untuk kehidupan yang lebih baik. Pada daerah seperti ini, kegiatan menghimpun dana maupun penyaluran dana sangat rendah. Sebaliknya, topografi dataran rendah biasanya pertanian dan perikanannya maju, jumlah penduduk pun banyak sehingga aktivitas ekonominya maju.

Bank unit yang sangat tidak efisien (inefisien tinggi) yaitu Bank Unit Pucakwangi berada di daerah yang topografinya pegunungan kapur yang gersang, sehingga kurang subur untuk pertanian. Bank unit yang topografi daerahnya lebih rendah dari aliran sungai, dan selalu meluap, seperti Bank Unit Jakenan juga menyebabkan bank unitnya sangat tidak efisien.

Bank unit yang berada di daerah yang topografinya rendah, biasanya pertanian maupun perikanan maju dan jumlah penduduknya banyak. Sehingga aktivitas ekonomi menggeliat dan bank-bank unitnya mencapai efisien, seperti bank unit Sukolilo dan bank unit Dukuhseti.

Banyak hal yang bisa dilakukan untuk membangun wilayah pinggiran maupun wilayah perdesaan, khususnya untuk wilayah yang bank-bank unitnya tidak mencapai efisien. Salah satunya adalah mendorong aliran modal ke daerah agar kegiatan ekonomi dan usaha masyarakat setempat bergeliat. Bank BRI secara aktif turun ke masyarakat memperkenalkan program KUR. Sosialisasi sangat penting agar masyarakat lebih mengenal dan dekat dengan perbankan. Apabila KUR semakin dikenal masyarakat, maka lambat laun masyarakat akan lepas dari jeratan rentenir yang selama ini menjadi sumber permodalan masyarakat desa. 
Akses permodalan harus dipermudah sebagai bagian dari program inklusi keuangan baik melalui transfer jaminan sosial maupun akses permodalan murah. Persyaratan yang memberatkan seperti jaminan benar-benar harus dihindari sesuai dengan tujuan KUR yaitu kredit usaha tanpa jaminan.

\section{DAFTAR PUSTAKA}

Allen, T. \& Arkolakis, C. (2014). Trade and the Topography of the Spatial Economy. The Quartely Journal of Economics, 129 (3), 1085-1140.

Anggraini, D. \& Nasution, S. H. (2013). Peranan Kredit Usaha Rakyat bagi pengembangan UMKM di Kota Medan (Studi kasus Bank BRI). Jurnal Ekonomi dan Keuangan, 1 (3).

Awunyo-Vitor, D. \& Abankwah, V. (2012). Substitutes or Complements?: Formal and Informal Credit Demand by Maize Farmers in Ashanti and Brong Ahafo Regions of Ghana. International Journal of Agriculture and Forestry, 2(3), 105112.

Balagobei, S. (2016). Efficiency of Micro Finance Institutions and Financial Sustainability in Jaffna District. Journal of Economics and Sustainable Development, 7 (24), 7.

Banerjee, S. B. \& Jackson, L. (2017). Microfinance and the Business of Poverty Reduction: Critical Perspectives from Rural Bangladesh. Human Relations, 70 (1), 62-91.

BPS. (2015). BPS Kabupaten Pati. https://patikab.bps.go.id/

Burger, А., Мурманн, Ю., Бургер, А., \& Moormann, J. (2008). Productivity in banks: myths \& truths of the cost income ratio. Bank and Bank Systems, 3 (4).

Chandio, A. A., Jiang, Y., Wei, F., Rehman, A., \& Liu, D. (2017). Famers' access to credit: Does collateral matter or cash flow matter?-Evidence from Sindh, Pakistan. Cogent Economics \& Finance, 5 (1), 1-13.
David, A. \& Rose, B. (2017). Challenges Facing Small Scale Entrepreneuresin Accessing Loan from Banks at Ngongongare, Meru District, Arusha Region in Tanzania. IOSR Journal of Business and Management, 19 (03), 103113.

Demirgüç-Kunt, A. \& Klapper, L. F. (2012). Financial inclusion in Africa: an overview.

https://elibrary.worldbank.org/doi/pdf/10. 1596/1813-9450-6088

Dilts, D. M., Zell, A. \& Orwoll, E. (2015). A Novel Approach to Measuring Efficiency of Scientific Research Projects: Data Envelopment Analysis: Novel Approach to Measuring Efficiency of Scientific Research Projects. Clinical and Translational Science, 8 (5), 495-501.

Duy, V. Q., D’Haese, L., Lemba, J., Hau, L. L., \& D'Haese, M. (2012). Determinants of Household Access to Formal Credit in the Rural Areas of the Mekong Delta, Vietnam. African and Asian Studies, 11 (3), 261-287.

Emekter, R., Tu, Y., Jirasakuldech, B., \& Lu, M. (2015). Evaluating credit risk and loan performance in online Peer-to-Peer (P2P) lending. Applied Economics, 47 (1), 54-70.

Farida, F., Osman, I. R., Lim, A. K., \& Wahyuni, N. (2018). Efficiency of Formal Microfinance in Indonesia: Using Data Envelopment Analysis Application. Iranian Economics Review, 22 (3), 787810.

Farida, F., Siregar, H., \& Nuryartono, N. (2016). An Impact Estimator Using Propensity Score Matching: People's Business Credit Program to Micro Entrepreneurs in Indonesia. Iranian Economic Review, 20 (4), 599-615. 
Gama, A. P. M. \& Duarte, F. D. (2015). Collateral and relationship lending in loan pricing: Evidence from UK SMEs. Wseas Transactions on Businesss and Economics, 12 (15). 21-35.

Khan, M. A. \& Rahaman, M. A. (2007). Impact of Microfinance on Living Standards, Empowerment and Poverty Alleviation of Poor People: Case Study on Microfinance in the Chittagong District of Bangladesh. Thesis. Umea School of Business (USBE). Bangladesh.

Kost, A., Laderach P, Fisher M, Cook S, \& Gomez L. (2012). Improving IndexBased Drought Insurance in Varying Topography: Evaluating Basis Risk Based on Perceptions of Nicaraguan Hillside Farmers. Plos ONE, 7(12),1-11.

Mayer, H., Habersetzer, A., \& Meili, R. (2016). Rural-Urban Linkages and Sustainable Regional Development: The Role of Entrepreneurs in Linking Peripheries and Centers. Sustainability, 8 (8), 745-758.

Parasuraman, A. (2010). Service productivity, quality and innovation: Implications for service-design practice and research. International Journal of Quality and Service Sciences, 2 (3), 277-286.

Sujarweni, V. W. \& Utami, L. R. (2015). Analisis Dampak Pembiayaan Dana Bergulir KUR (Kredit Usaha Rakyat) Terhadap Kinerja UMKM. Jurnal Bisnis dan Ekonomi, 22 (1), 11-24

Thanassoulis, E. \& Silva, M. C. A. (2018). Measuring Efficiency Through Data Envelopment Analysis. Impact, 2018 (1), $37-41$.

Zhang, Q. (2017). Does Microfinance Reduce Poverty? Some International evidence. The B. E. Journal of Macroeconomics, 17 (2). 